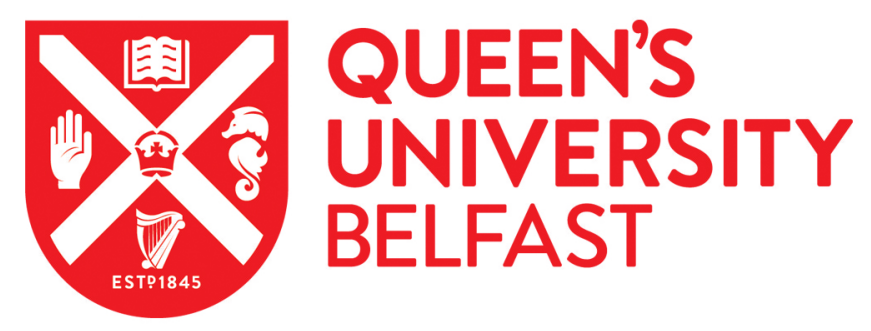

\title{
Assessing lake ecological status across a trophic gradient through environmental and biological variables
}

Macintosh, K. A., Cromie, H., Forasacco, E., Gallagher, K., Kelly, F. L., McElarney, Y., O'Kane, E., Paul, A., Rippey, B., Rosell, R., Vaughan, L., Ward, C., \& Griffiths, D. (2019). Assessing lake ecological status across a trophic gradient through environmental and biological variables. Science of the Total Environment, 690, 831-840. https://doi.org/10.1016/j.scitotenv.2019.07.038

Published in:

Science of the Total Environment

Document Version:

Peer reviewed version

Queen's University Belfast - Research Portal:

Link to publication record in Queen's University Belfast Research Portal

Publisher rights

Copyright 2019 Elsevier.

This manuscript is distributed under a Creative Commons Attribution-NonCommercial-NoDerivs License

(https://creativecommons.org/licenses/by-nc-nd/4.0/), which permits distribution and reproduction for non-commercial purposes, provided the author and source are cited.

\section{General rights}

Copyright for the publications made accessible via the Queen's University Belfast Research Portal is retained by the author(s) and / or other copyright owners and it is a condition of accessing these publications that users recognise and abide by the legal requirements associated with these rights.

Take down policy

The Research Portal is Queen's institutional repository that provides access to Queen's research output. Every effort has been made to ensure that content in the Research Portal does not infringe any person's rights, or applicable UK laws. If you discover content in the Research Portal that you believe breaches copyright or violates any law, please contact openaccess@qub.ac.uk. 
1 Assessing lake ecological status across a trophic gradient through environmental and

2 biological variables

3

4 Katrina A. Macintosh ${ }^{a, b *}$, Hannah Cromie $^{c}$, Elena Forasacco ${ }^{a, d}$, Kevin Gallagher $^{c}$, Fiona L. Kellye,

5 Yvonne McElarneyc ${ }^{c}$, Eugene O'Kane ${ }^{c}$, Andrew Paul ${ }^{c, f}$, Brian Rippey ${ }^{a}$, Robert Rosell ${ }^{c}$, Louise

6 Vaughan ${ }^{c, g}$, Colleen Ward ${ }^{c}$ and David Griffiths ${ }^{a}$

7

$8 \quad{ }^{a}$ School of Geography and Environmental Sciences, Ulster University, UK

9 b School of Biological Sciences and the Institute for Global Food Security, The Queen's University of

10 Belfast, UK

$11{ }^{\mathrm{c}}$ Agri-Food and Biosciences Institute, Belfast, UK

12 d Graduate School, Imperial College London, UK

13 e Inland Fisheries Ireland, Dublin, Ireland

$14{ }^{f}$ Department of Finance, Northern Ireland Civil Service, Belfast, UK

159 Galway Mayo Institute of Technology, Galway, Ireland

16

$17 \quad{ }^{*}$ Corresponding author.

18 E-mail address: k.macintosh@qub.ac.uk 


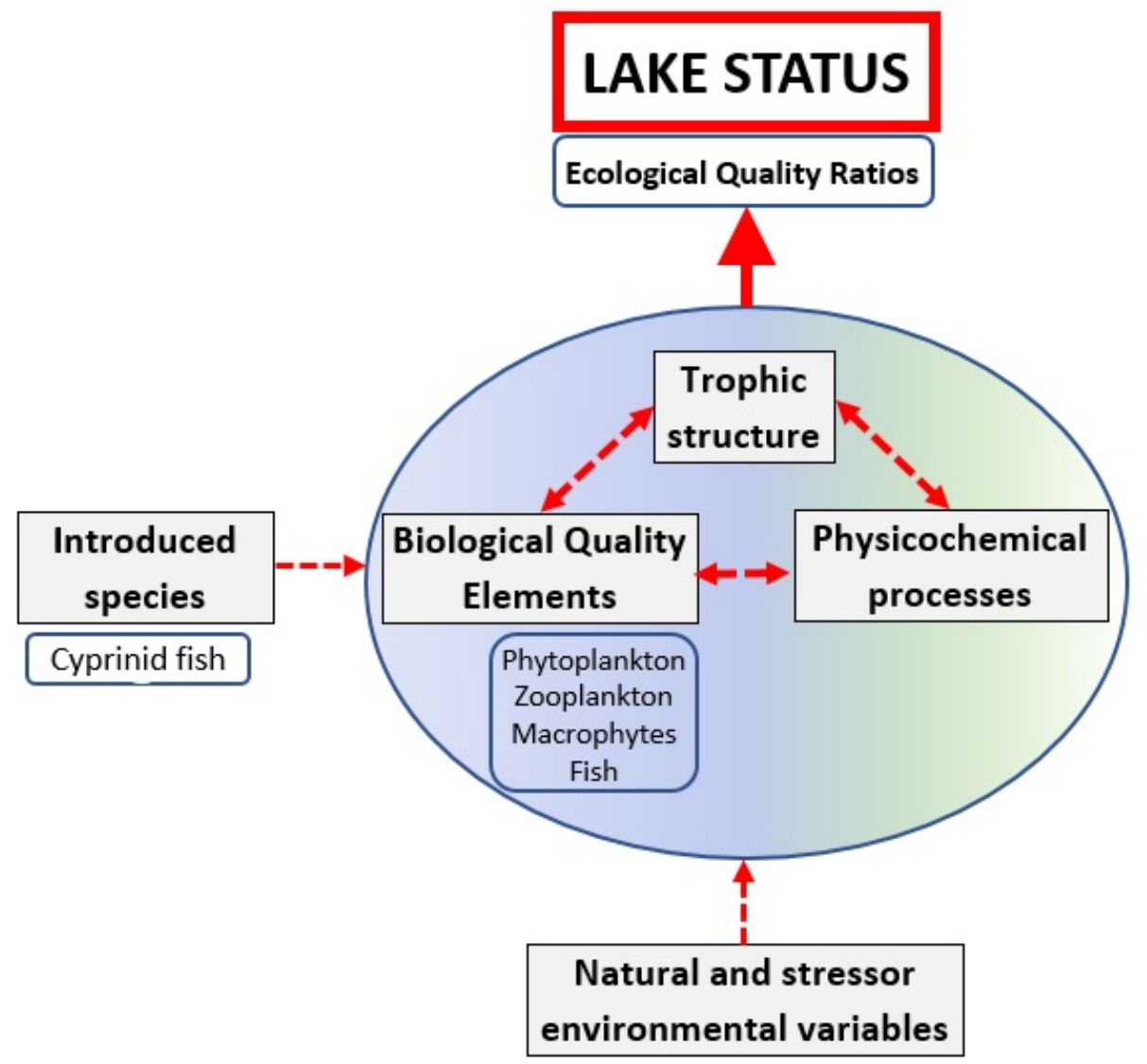




\section{Highlights}

- Contributions of environmental and biotic variables were determined for 50 lakes

- Strong evidence for bottom-up rather than top-down trophic effects detected

- Lakes with introduced cyprinid fish had lower ecological quality

- Limited concordance in the responses of BQEs to environmental variables

- Chlorophyll a, TP, population density, water colour and elevation predict mean EQR 


\section{Abstract}

28 The Water Framework Directive was widely welcomed because it sought to integrate chemical and biological elements of aquatic ecosystems to achieve 'good ecological status', reflecting at most slight anthropogenic impact. However, implementation has been criticised because of the failure to adequately integrate these elements and assess status of the whole ecosystem. In this study, a suite of environmental and biotic variables was measured to assess their relative importance as predictors of lake status for 50 lakes in the north of the island of Ireland. Total Phosphorus (TP) had a strong effect on taxon biomasses and ecological quality ratios (EQR) for most taxa, as expected, but other environmental variables, such as $\mathrm{pH}$, water colour and spatial location, were also important. Most variance in mean EQR, the average of the taxon values, was predicted by five environmental variables (chlorophyll a, TP, population density, water colour and elevation) and whether (alien) cyprinid fish were present. Oligotrophic lakes with cyprinid fish had lower mean EQRs than cyprinidfree lakes, indicating the importance of recording species introductions when assessing lake status. Strong evidence for bottom-up effects was also detected, and cyprinids probably influenced trophic structure by increasing nutrient release from the sediment rather than by top-down effects. Phytoplankton biomass, fish biomasses, and the percentage of predatory fish, increased with TP. Our results further emphasize the need to adopt a more integrated approach when assessing lake status. introductions; Trophic structure 


\section{Introduction}

Lake trophic state is affected by natural intra-lacustrine and catchment-scale processes, and anthropogenic influences. Eutrophication typically changes ecosystem structure and functioning by increasing phytoplankton abundance and dominance by filamentous cyanophytes, with consequent reductions in photic depth, macrophyte loss and a shift in the fish community to benthic feeding species, which compound such impacts through increased internal nutrient re-circulation (Moss, 1998; Scheffer, 1998; Smith, 2003). In addition to these largely nutrient determined bottom-up processes, top-down predator-prey (consumption) effects are regarded as important in controlling ecosystem structure and function (Leibold et al., 1997). For example, fish selectively consume larger zooplankters, particularly the more efficient grazer cladocerans, with positive effects on phytoplankton abundance (Hall et al., 1976).

Phosphorus $(P)$ is generally regarded as a major driver of eutrophication and hence trophic structure but other factors are important. For example, nitrogen $(\mathrm{N})$ compounds can have significant acidification, eutrophication and toxicity effects on biota (Camargo \& Alonso, 2006). While P and N concentrations are often correlated (Downing \& McCauley, 1992) oligotrophic lakes are generally Plimited, whereas N-limitation is more likely in eutrophic water bodies (Sterner \& Elser, 2002). Nutrient limitation can affect species composition: for example, cyanophytes are more likely to dominate in Prich lakes as some species can fix atmospheric $\mathrm{N}$, and thus are not limited by water-column $\mathrm{N}$. Water colour also affects phytoplankton composition and biomass, and overall lake productivity (Nürnberg \& Shaw, 1999; Carvalho et al., 2011). Furthermore, species introductions are known to alter lake trophic state. For example, cyprinids such as roach (Rutilus rutilus) and bream (Abramis brama), species characteristic of eutrophic waters, can reduce zooplankton abundance and release nutrients from lake sediments through bioturbation, with effects on the abundance of phytoplankton and consequently of macrophytes (Winfield \& Townsend, 1991; Scheffer, 1998), while zebra mussels (Dreissena polymorpha) can have major impacts on lake plankton, benthos and fish and thus on ecosystem function (Maclsaac, 1996).

The European Union Water Framework Directive 2000/60/EC (WFD) seeks to assess anthropogenic impacts on water bodies by comparing observed lake conditions with those expected for unimpacted lakes. The WFD defines ecological status as an expression of the quality of aquatic ecosystem structure and functioning, using physical, chemical and biological quality elements. To 
simplify the establishment of reference conditions a set of habitat types is defined using features that are regarded as insensitive to human impact. For example, lake area, mean depth and alkalinity are used to classify lake types in the Republic of Ireland (Free et al., 2016). Considerable effort has been expended in establishing procedures for calculating ecological quality ratios (EQR, the ratio of observed/unimpacted (reference) lake conditions) (Poikane et al., 2015). Implementation of the WFD has, however, been heavily criticised because of the failure to integrate the biological quality elements (BQE) to provide a holistic view of lake quality (Moss, 2008; Voulvoulis, Arpon \& Giakoumis, 2017), instead focussing more on ecosystem structure (abundances) than function (the interactions between BQEs) (Caroni \& Irvine, 2010). Not all potentially important elements (such as zooplankton, Jeppesen et al., 2011) are measured or, if measured, taken into account (in the 'one-out, all-out' principle) when determining lake status. Furthermore, species introductions are not explicitly considered, notwithstanding their potentially significant effects on ecosystem function and interactions with other factors; for example, as outlined above, cyprinids are characteristic of eutrophic waters and can also increase nutrient concentrations by bioturbation. Both bottom-up and top-down processes are important in regulating lake trophic structure (Carpenter \& Kitchell, 1993; Jeppesen et al., 1997; Vanni, 2002; Jeppesen et al., 2003). For example, Carpenter and Kitchell (1993) noted that nutrient supply accounted for only half the variance in primary production and concluded that there were strong trophic interaction effects in their three study lakes. However, the WFD considers nutrient effects but does not take account of top-down processes, i.e. consumptive interactions between the BQEs, with the danger of missing important key predictors of EQRs.

In this study, the relationships between a number of natural and stressor environmental variables and phytoplankton, macrophyte, zooplankton and fish assemblages were explored to identify the relative importance of factors driving taxa abundances and composition and their interactions, and hence ecosystem structure and function, across a lake trophic gradient. We take an integrated view of the effects of multiple metrics on lake ecosystems by addressing the following questions:

1) Which environmental variables best predict phytoplankton, macrophyte, zooplankton and fish biomasses and are these BQE responses concordant across taxa?

2) Which environmental and biotic variables best predict EQRs? 
3) Do trophic interactions have measurable effects on taxon biomasses and EQRs? Specifically, is there evidence of (a) bottom-up and/or top-down effects (positive and negative correlations between BQE biomasses, respectively), (b) selective predation on zooplankton by fish (decreases in zooplankton:phytoplankton ratio, Daphnia abundance, and zooplankton size with increasing fish predation), and (c) interactions between and within BQEs varying with eutrophication?

\section{Methods}

\subsection{Study lakes and measures} Fifty, mainly small and shallow, lakes (Table S1a) in the north of the island of Ireland (Fig. 1) were selected to incorporate a trophic gradient, ranging from oligotrophic in the west to eutrophic conditions in the east. Lake chemistry, phytoplankton and zooplankton were sampled seasonally, in spring (March-May), summer (June-August) and autumn (September-November) in 2012 or 2013, while macrophytes and fish were sampled once, in the summers of those years. Total phosphorus (TP), total oxidised nitrogen (TON), ammoniacal nitrogen $\left(\mathrm{NH}_{4} \mathrm{~N}\right)$, chloride $(\mathrm{Cl})$, soluble reactive silica $\left(\mathrm{SiO}_{2}\right), \mathrm{pH}$, alkalinity, water depth, water colour were measured as direct, and lake area and elevation as indirect, potential influences on taxon biomasses. Human population density within the catchment (PopDen) and \% of the catchment used for agriculture were recorded as possible indicators of anthropogenic impact. The presence or absence of zebra mussels was noted. Hydrological condition was not assessed but, as far as we know, water level is not regulated in any of the lakes.

\subsection{Sampling and laboratory analysis procedures}

\subsubsection{Water chemistry}

A composite mixed layer water sample was collected at the deepest point of each lake using a $500 \mathrm{ml}$ Ruttner water sampler. Water temperature, and dissolved oxygen concentration, conductivity and pH were measured at $1 \mathrm{~m}$ depth intervals using a YSI 556 MPS multi-probe. Chlorophyll a (Chla) was determined by spectrometry using the procedure of Marker, Crowther and Gunn (1980) after cold extraction in the dark at $4{ }^{\circ} \mathrm{C}$. Water colour (Hazen) was determined by spectrometry using potassium chloroplatinate and cobaltous chloride hexahydrate (Standing Committee of Analysts, 1984). A Mettler DL25 autotitrator, was used to measure $\mathrm{pH}$ and determine alkalinity by acidometric titration to $\mathrm{pH} 4.5$ (Standing Committee of Analysts, 1979, 1982). Composite water sub-samples were preserved by 
freezing for the determination of TP, TON and $\mathrm{SiO}_{2}$. TP was analysed following the method of Eisenreich, Bannerman and Armstrong (1975). $\mathrm{TON}$ and $\mathrm{NH}_{4} \mathrm{~N}$ were determined using the methodologies of Chapman, Cokke \& Whitehead (1967) and Scheiner (1976). SiO 2 was measured spectrophotometrically according to Golterman, Clymo \& Ohnstad (1978).

\subsubsection{Phytoplankton}

An unfiltered sub-surface (approximately $0.3 \mathrm{~m}$ depth) phytoplankton sample was collected using a $250 \mathrm{ml}$ brown polypropylene bottle at the lake deepest point and preserved using acidified Lugol's iodine. Sample counts were performed using the Ütermohl technique on an inverted microscope (CEN, 2006). Taxa were identified using John, Whitton \& Brook (2011), Kelly (2000), Cox (1996), Komarek and Anagnostidis (1999, 2007), Bellinger and Sigee (2010), Canter-Lund and Lund (1995) and Komárek (1999). Biovolumes were calculated from recorded cell counts and measured cell dimensions which were then approximated to simple geometric shapes (Mischke et al., 2012).

\subsubsection{Macrophytes}

Sampling followed the UKTAG (2008) procedure. A shoreline investigation of littoral macrophytes was conducted $10 \mathrm{~m}$ either side of transect starting locations. Transects ran perpendicular to the shore and samples were taken at $0,2.5,5,7.5,10,25,50,75$, and $100 \mathrm{~m}$ along transects. The number of transects was determined by lake size and shoreline complexity: at least four transects were taken per lake. For each transect the maximum depth of colonisation was recorded. When plant presence was recorded at one position but not at the next, the previous position was returned to and sampled at every depth change of $0.5 \mathrm{~m}$ until the maximum depth of colonisation was located. If plants were found to occur at the $100 \mathrm{~m}$ distance, the survey was continued for every $0.5 \mathrm{~m}$ change in depth, until the maximum depth and distance of colonisation was found. A double-headed rake was used to take four macrophyte samples at each sampling position. Macrophytes were identified to species using standard works (Rose, 1981; Moore, 1986; Hill, Preston \& Smith, 1991-4; Preston, 1995; Preston \& Croft, 1997).

\subsubsection{Zooplankton}


Five vertical zooplankton net hauls were collected per lake, using a net and filter of mesh $250 \mu \mathrm{m}$ : nets with this mesh size do not sample small zooplankters such as rotifers. Haul depths were selected relative to lake internal shape. Each lake was divided into five vertical sections, of equal volume, based on the hypsometric curve of that lake. A vertical net haul was then taken from the mean depth of each section. Aliquots of each of the five net hauls were combined, relative to haul volume, to form a composite sample for each lake. While the water depth of each haul was predetermined, sampling position in the lake was selected at random. Samples were preserved in $70 \%$ industrial methylated spirits. A sub-sample was then enumerated using an Olympus SX15 binocular microscope, cladocerans and copepods were identified using keys (Scourfield \& Harding, 1966; Harding \& Smith, 1974), and zooplankton densities (numbers $\mathrm{L}^{-1}$ ) calculated.

\subsubsection{Fish}

Fish were sampled in 46 of the 50 study lakes, using a standardised combination of benthic monofilament gill nets, floating monofilament gill nets and fyke nets (Kelly et al., 2008). The procedure was an adaptation of the CEN standard for sampling fish using multi-mesh gill nets (CEN, 2005). Lakes were allocated to six area classes $(\leq 20,21-50,101-250,251-1000,1001-5000$ ha), each with a prescribed number of nets to be deployed in each depth zone: the number of nets utilised increased with maximum depth and surface area. Nets were left overnight, for approximately 18 hours. Depending on bathymetry, lakes were randomly sampled at depth strata $(0-2.9,3-5.9,6-11.9,12-$ 19.9, 20-34.9 and 35-49.9 $\mathrm{m}$ strata). The multi-panel gill nets were CEN compliant (length $30 \mathrm{~m} \mathrm{x}$ depth $1.5 \mathrm{~m}$, consisting of $12 \times 2.5 \mathrm{~m}$ panels of different mesh sizes following a geometric series ranging from 5 to $55 \mathrm{~mm}$, knot to knot). Floating pelagic gill nets with identical dimensions to the benthic gill nets were deployed over the deepest sections of the study lakes. Each survey was supplemented with a minimum of three fyke net units (three nets per unit: each net total length of 10 $\mathrm{m}$ and hoop diameters of $0.5,0.45,0.35$ and $0.28 \mathrm{~m}$, mesh $22 \mathrm{~mm}$ knot to knot). Fish biomass was estimated as $\mathrm{g} \mathrm{m}^{-1}$ net: following the FIL2 (Kelly et al., 2012) protocol fyke net catches were calculated, like gill nets, as $\mathrm{m}^{-1}$ net. Fish were identified to species and measured (fork length $\pm 1 \mathrm{~mm}$, blotted wet mass $\pm 0.1 \mathrm{~g}$ ). A sub-sample of fish were aged: scales were taken from cyprinids, opercular bones from perch and pike, and sagittal otoliths from eels. 
The macrophyte category included bryophytes and macroalgae as well as angiosperms. The zooplankters Daphnia galeata and D. hyalina form a species complex and were grouped (Caroni \& Irvine, 2010). All roach, rudd, bream hybrids were allocated to a Hybrid category. Phytoplankton abundance was estimated as Chla concentration and total cell biovolume. Macrophytes were assigned a DAFOR (Dominant (5); Abundant (4); Frequent (3); Occasional (2) and Rare (1)) numeric score based on estimated percentage occurrence in rake samples. Relative abundances in each lake were estimated as the sum of the DAFOR scores, scaled by the mean depth of species presence as a proportion of maximum lake depth. Zooplankton biomass was estimated as $\mu \mathrm{g} \mathrm{DW}$ litre $^{-1}$, from lengthweight regression equations in Downing and Rigler (1984). To simplify presentation all these (density) measures are referred to as biomasses.

Area, mean depth and alkalinity are used to identify WFD lake types in the Republic of Ireland (Free et al., 2016). Alkalinity and conductivity were strongly collinear and were replaced by the morphoedaphic index (MEI, calculated as alkalinity/mean lake depth) as an indicator of nutrient availability (Chow-Fraser, 1991). While many of the environmental variables were correlated with the $\%$ of the catchment used for agriculture (Table S1b) inclusion of this variable did not improve prediction of taxon biomass or EQR and is not reported.

There was some seasonal variation in taxon and environmental variables but 'annual' means were calculated to simplify the analysis and because overall lake status measures should be insensitive to seasonality. To normalise the data, most variables, including trophic level biomass ratios, were $\log _{10}$ transformed but elevation was square-root transformed and $\mathrm{pH}$ was normally distributed: unless otherwise stated the results are based on transformed values. The number of observations per BQE varied (phytoplankton 50, macrophytes 48, zooplankton 50, fish 46 lakes). EQRs were calculated for phytoplankton biovolumes using the associated software (UKTAG, 2014), macrophyte scores using the Free Index (UKTAG, 2008) and fish using FIL2 (Kelly et al., 2012). Phytoplankton EQRs require information on Chla and taxon biovolumes, macrophyte EQRs information on depth of occurrence, and the relative occurrence of Chara species and elodeids; both 
EQRs use information on taxon-specific sensitivity to TP concentrations. Fish EQRs use information on 13 variables covering species composition, catch and biomass per unit effort. Mean EQR was the average of these scores across BQEs. BQEs were weighted equally, but boundary values for the quality classes differed across BQEs e.g. high/good quality $0.8,0.9,0.76$ for phytoplankton, macrophytes, fish, respectively. However, rescaling to the same boundary values had no effect on predicted mean EQR values. The missing macrophyte and fish EQR values were estimated from observed EQR-environmental variable regressions (macrophyte EQR $=1.251-0.318^{\star} \mathrm{TP}-0.148^{*} \mathrm{Colour}-$ $0.095^{\star} \mathrm{MEI}, R^{2}=0.63$; fish $\mathrm{EQR}=0.219-0.260^{*} \mathrm{MEI}, R^{2}=0.30$ ). Phytoplankton genus/species optimal responses to TP (from Appendix A in UKTAG, 2014) were weighted by their corresponding biovolumes to calculate mean lake phytoplankton response to TP. For each lake, the upper and lower quartile optima, unweighted by biovolume, were also calculated; these quartile optima correspond to species tolerant and intolerant of TP, respectively. Relations between environmental variables were summarised using principal components analysis (PCA), relations between environmental variables, $B Q E$ biomasses and EQRs investigated using pairwise Pearson ( $r$ ) correlation coefficients while environmental variable differences between lakes with and without cyprinids and with and without zebra mussels were examined by linear discriminant analysis. Boosted regression trees (BRT) were used to estimate the relative contributions of the environmental predictors to taxon biomasses and EQRs. Biomass-environmental variable correlation coefficient values (Table S2) were correlated with the BRT relative influence values

244 (coefficients ranged from 0.72 to 0.86 across the four BQEs). Means are shown with standard errors. Most statistical calculations were conducted using Systat v13.

BRT is a machine-learning method which can handle continuous and categorical variables, and avoids many of the problems of more traditional regression approaches (Elith, Leathwick \& Hastie, 2008). Code provided by Elith et al. (2008), modified from the 'dismo' (Hijmans et al., 2016) and 'gbm' (Ridgeway, 2015) packages, was used in R 3.1.2 (R Development Core Team, 2014). Optimal models were fitted by altering the number of regression trees generated and the learning rate (a parameter that determines the contribution each tree makes to the model) to minimize predictive deviance. Final models used a learning rate of 0.005 , tree complexity (the number of splits in a tree) of two and bag fraction (proportion of data used when selecting optimal tree number) of 0.75 . Variable 
importance was assessed by relative influence, the proportion of times that a variable is used to split a tree, weighted by the improvement in model fit by adding that tree.

\section{Results}

\subsection{Environmental trends}

The first three factors of the PCA accounted for $66 \%$ of the variance in environmental variables (Table 1). The first axis corresponds to a nutrient gradient, from clear water, nutrient-rich, lakes to coloured water, low nutrient, lakes, and the second to a lake area/elevation gradient, lowland lakes being larger, with higher $\mathrm{N}$ concentrations and greater catchment population densities than upland lakes. There is a strong spatial component to this variation in environmental variables, which potentially reflects anthropogenic activity. $\mathrm{TP}, \mathrm{pH}, \mathrm{TON}, \mathrm{SiO}_{2}, \mathrm{PopDen}$ and $\mathrm{MEI}$ were greater in the east (and south), while colour and lake size were greater in the west (Table 1). Chloride was greater in lakes close to the coast.

\subsection{Biomass- environment relations}

TP had the largest relative influence value for phytoplankton and fish biomasses (Table 2). In contrast, PopDen, MEI and elevation were most influential for macrophytes, while water colour and $\mathrm{SiO}_{2}$ were influential for zooplankton.

Some within-BQE compositional differences were correlated with environmental variables. Most correlations (19/28; 68\%) between phytoplankton phyla biomasses were significant and positive, and phyla biomasses increased with TP $\left(F_{1,346}=54.22, P<0.001\right)$. However, there was little evidence of a systematic change in phyla dominance with enrichment; \% biomass-TP slopes did not differ significantly across phyla $\left(F_{7,384}=1.90, P>0.05\right)$. Daphnia spp. biomass increased with $\mathrm{NH}_{4} \mathrm{~N}$ and PopDen, whereas the biomass of the other herbivorous cladocerans increased with water colour and declined with $\mathrm{pH}, \mathrm{MEI}, \mathrm{PopDen}$ and $\mathrm{SiO}_{2}$ (Table S2). Discriminant analysis showed that $\mathrm{pH}$ alone correctly identified $76 \%$ of lakes with or without cyprinids (mean $\mathrm{pH} 7.23 \pm 0.14,6.37 \pm 0.15$, respectively). Fish biomass in cyprinid-free lakes was predicted by area $(r=0.55, P<0.01)$, whereas $\mathrm{MEl}$ and $\mathrm{NH}_{4} \mathrm{~N}$ predicted fish biomass in lakes with cyprinids $(r=0.84, P<0.001)$. The biomass of the potential bioturbators, roach, bream and tench (Tinca tinca) comprised $13.4 \%$ (range $0-84 \%$ ) of total fish biomass, and increased with TP (Table S2). 
The environmental variables examined had predominantly negative effects on EQR scores (sum of negative relative influence values varied from 74 to $98 \%$ across BQEs). TP had the largest relative influence value on EQR scores for phytoplankton and macrophytes, whereas MEI and PopDen were most influential for fish EQRs (Table 2). EQR relative influence values for phytoplankton and macrophytes were correlated, but neither was correlated with that for fish $(r=0.73,-0.25,0.08$, respectively). Low EQR scores were associated with large biomasses for phytoplankton and fish but not for macrophytes (Table 3). EQR scores also varied spatially (Table 3, Fig. 1), suggesting that the spatial variation is at least partly due to anthropogenic impact.

EQR scores for phytoplankton, macrophytes and fish were positively, albeit weakly, correlated across lakes $(r=0.36,0.45,0.53$, all $P<0.01)$. Eighty-two \% of variation in mean $\mathrm{EQR}$, the average of the three EQR scores, was predicted by cyprinid presence/absence and five environmental variables, namely TP, Chla:TP ratio, PopDen, water colour and elevation (Table 4; mean EQR cyprinids present $0.501 \pm 0.026, n=24$; cyprinids absent $0.752 \pm 0.028, n=22$ ). This model did not show collinearity amongst predictors (all variance inflation factors $<1.9$ ). Observed mean EQR was strongly correlated with predicted scores (Fig. 2) and, for example, $65 \%$ of lakes were correctly assigned to $0.2,0.4,0.6$ and $0.8 \mathrm{EQR}$ boundary classes and this rose to $87 \%$ when including values within 0.02 of a boundary class.

Mean EQR was consistently greater in cyprinid-free lakes for all environmental variables. For example, cyprinid-free lakes had higher mean EQR scores at low TP concentrations, but this difference declined in eutrophic lakes (Fig. 3a; ANOVA TP $F_{1,42}=23.51, P<0.001$, TP-cyprinid occurrence interaction $F_{1,42}=10.19, P<0.01, \mathrm{TP}^{2}$-cyprinid occurrence interaction $F_{1,42}=5.66, P<0.05$, $\left.R^{2}=0.68\right)$. Similarly, mean EQR scores declined more steeply with Chla and were lower in lakes with cyprinids, except in the most Chla-rich lakes (Fig. 3b; for Chla $<10 \mu \mathrm{L}^{-1}$ slopes $F_{1,31}=46.14, P<0.001$, $R^{2}=0.81$; mean EQR $\left.F_{1,32}=35.70, P<0.001\right)$. Note that whereas mean $E Q R$ declined with increasing TP it appeared to increase with Chla in eutrophic (TP>40 $\left.\mu \mathrm{g} \mathrm{L}^{-1}, \mathrm{Chla}>10 \mu \mathrm{g} \mathrm{L}-1\right)$ lakes with cyprinids, suggesting a change in phytoplankton composition in these lakes. 
314 Across lakes, there were no correlations between phytoplankton and macrophyte biomasses $(r=-0.17$, $315 P>0.2)$ or between adjacent trophic level biomasses. The Macro:Phyto and Zoo:Phyto ratios were 316 greater in acidic, low nutrient lakes (Table 5) but the Zoo:Phyto ratio-TP slope $(-0.81 \pm 0.24)$ was not 317 different from -1.0, consistent with no change in zooplankton grazing impact across the nutrient gradient. However, the Zoo:Phyto biomass ratio declined with increasing cyprinid biomass $(r=-0.36$, $P<0.05)$ but this occurred because phytoplankton biomass increased and not because zooplankton biomass decreased $(r=0.35, P<0.05, r=-0.04, P>0.7)$.

Phytoplankton composition changed with eutrophication, with TP-tolerant taxa more abundant in cyprinid lakes (Fig. S1a). Both the upper and lower quartile TP optima were significantly greater in lakes with cyprinids (Fig. S1b) but the sensitive taxa (lower quartile) optima varied with Chla only in cyprinid-free lakes.

Total zooplankton biomass and mean size were not correlated with any phytoplankton or fish biomass measures (Table 6). Across lakes, copepods comprised 43\% (range $<1-99 \%$ ) of zooplankton biomass and calanoid biomass declined with increasing cyprinid biomass. Neither cladoceran and copepod biomasses nor Daphnia and other cladoceran biomasses were correlated $(r=0.25, P>0.05$; $r=0.19, P>0.2$, respectively). However, Daphnia spp. biomass, and the $\%$ contribution of Daphnia to total cladoceran biomass, increased with fish biomass while that of the other grazer cladocerans declined. The biomass and mean size of small cladocerans (mean species mass $<3.0 \mu \mathrm{g} \mathrm{DW}$ ), which comprised an average of $13 \%$ (range $0-86 \%$ ) of grazer cladocerans, declined as cyprinid biomass increased but no fish effect was detected on Daphnia or copepod sizes. Only two of 23 zooplankton species differed in mean size with cyprinid presence/absence and these small species (Bosmina longirostris, Diaphanosoma) were larger in cyprinid free lakes i.e. at the species level there is no evidence for a fish size-selective predation effect.

Cyprinid, like total fish, biomass increased with TP (Table S2). Total fish biomass was greater in lakes with cyprinids than in cyprinid-free lakes (ANOVA $F_{1.44}=24.02$; biomass $92.06 \pm 8.26$, $33.51 \pm 8.63 \mathrm{~g} \mathrm{~m}^{-1}$ net respectively). Trout (Salmo trutta) were found in unproductive lakes (Chla

$\left.340 \quad F_{1.44}=26.52, P<0.001\right)$ and rarely with cyprinids $\left(\chi^{2}=19.60, P<0.001\right)$. Pike (Esox lucius) biomass 341 increased with that of cyprinids, but trout biomass declined $(r=0.59, P<0.001,-0.56, P=0.01)$. Pike 342 biomass as a $\%$ of total fish biomass was greater in more productive lakes (Table 5; Chla $r=0.41$, 343 $P<0.01)$. Zebra mussels occurred in seven lakes and these lakes had significantly greater cyprinid 
biomass than mussel-free lakes $\left(F_{1.44}=24.79 ; 75.00 \pm 11.37, n=7 ; 13.55 \pm 4.82, n=39 \mathrm{~g} \mathrm{~m}^{-1}\right.$ net, respectively); discriminant analysis also showed that Chla was lower, zooplankton biomass and $\mathrm{pH}$ greater in lakes with zebra mussels.

\section{Discussion}

This study, in general, confirms previously established taxon-nutrient relationships (see section 4.1) but is novel in examining the importance of other key environmental variables, ecological interactions, and species introductions, when assessing lake status. Across the 50 study lakes, TP had a strong effect on biomasses and EQRs for most taxa, but other environmental variables were also important; for example, TP, $\mathrm{pH}, \mathrm{NH}_{4} \mathrm{~N}, \mathrm{SiO}_{2}$ and $\mathrm{MEl}$ all had correlation coefficients $>0.5$ for at least some $\mathrm{BQEs}$. However, only one of six biomass - environment correlation coefficients (for phyto--zooplankton), and none of the BRT relative influence - environment correlation coefficients, were significantly correlated across BQEs, i.e., there was little concordance in BQE responses to environmental variables. We show that trophic interactions affected taxon biomasses and EQRs, with mean EQR being up to 0.2 less in cyprinid lakes. Surprisingly, the majority of work to-date on the implementation of WFD procedures has focussed on single BQEs (Lyche-Solheim et al., 2013), whereas Jeppesen and colleagues (for example, Jeppesen et al., 2000; 2003) have taken a more integrated view of lake condition along TP gradients, but did not assess EQR status.

\subsection{Environmental variables and taxon abundance and composition}

There is a broad agreement between the effect of environmental variables on taxon composition in this study and previous findings. Cyanophytes, chlorophytes and diatoms comprised $83 \%$ of phytoplankton biomass, but, we found little evidence of a systematic change in phyla dominance across the enrichment gradient. Järvinen et al. (2012) showed that pristine northern European lakes tend to be dominated by chrysophytes, with chlorophytes also being important in clearwater lakes and dinophytes in humic lakes, while cyanophytes increased with declining lake status.

Macrophytes in our study lakes, which tended to be to the west and south of those examined by Heegaard et al. (2001), were most abundant at low elevations in high MEl catchments. Heegaard et al. (2001) noted a strong altitudinal influence on macrophyte composition in Northern Ireland, with nutrient-rich lakes being restricted to lowland areas. In our lakes, the macrophyte:phytoplankton ratio 
was greater in oligotrophic lakes, consistent with a negative interaction between these groups driven by changes in light regime and nutrient supply (Scheffer \& van Nes, 2007).

Jeppesen et al. (2003) showed that the \% Daphnia increased in shallow lakes up to $150 \mu \mathrm{g} \mathrm{L}$

1 TP: in our lakes \% Daphnia did not change with TP but did increase with Chla. Our fish composition results are consistent with previous findings (Persson et al., 1991; Olin et al., 2002), with salmonids characteristic of oligotrophic lakes and cyprinids of eutrophic waters.

\subsection{Determining lake status}

We did not sample dissolved organic matter, bacteria, small zooplankters, benthic algae or invertebrates, all of which can be important to understanding ecosystem structure and function (Arndt, 1993; Nürnberg \& Shaw, 1999; Jones \& Sayer, 2003). The extent to which these biological elements are concordant with those required by the WFD needs to be established to determine the optimal number of variables necessary for adequate monitoring of overall lake quality (Moss, 2007).

The best way to combine EQRs across BQEs and determine overall lake status is not straightforward (Caroni et al., 2013). However, averaging is close to the spirit of the WFD as an "expression of the quality of the structure and functioning of aquatic ecosystems" because mean EQR integrates quality ratios, whereas application of the current 'one-out, all-out' principle can result in a lake's status being determined by just a single BQE. The mean EQR equation had a lower standard error of estimate than predictive EQR regressions for macrophytes and fish and performed as well as the phytoplankton EQR regressions i.e. did not increase predictive variance. In our lakes, mean EQR was predicted by cyprinid presence/absence, TP, Chla:TP ratio, PopDen, water colour and elevation, with the first three variables having the strongest effects. While the last two variables are clearly not direct indicators of anthropogenic impact they are weakly correlated with PopDen (Table S1b). The Chla:TP ratio was included as a potential predictor because Chla cell concentrations vary considerably across taxa (Reynolds, 2006) and because Chla-nutrient relationships vary with lake type (Phillips et al., 2008).

The mean EQR-environmental variable relationship accounted for $82 \%$ of the variance in our lakes but its predictive utility needs to be tested by comparing observed and predicted values for other lakes within this ecoregion. Lyche-Solheim et al. (2013) compared many of the metrics used when assessing BQE responses but did not include cross-taxon comparisons. Although the need, central to 
the WFD, for an integrated approach when assessing lake status is recognised (Moss, 2008; Kelly et al., 2016; Voulvoulis et al., 2017), the only other cross-taxon analysis of which we aware is that of Free et al. (2016). They found that TP explained $84 \%$ of the variation in the mean of EQRs for phytoplankton, phytobenthos and macrophytes in Ireland: the contribution of other environmental variables was not examined. Phytoplankton, macrophyte and benthic macroinvertebrate EQRs declined with increasing TP for 32 large lakes in Finland but there was no trend for fish (Rask et al., 2011) and a mean EQR was not calculated.

Many of the WFD assessment methods were established using BQE responses along a TP gradient, so strong TP responses are to be expected. However, BQEs respond to different parts of the ecosystem (pelagic, benthic) at different time scales (rapid for phytoplankton, slow for macrophytes and fish) so some differences in response are likely. In our study, TP was the most influential predictor for phytoplankton and fish biomasses but not for macrophytes or zooplankton. The different macrophyte response may be due to rooted species obtaining their nutrients from the sediment rather than from the water column. Free et al. (2016) did observe similar macrophyte and phytoplankton responses to TP using the same macrophyte index, but a different phytoplankton one to this study. Ireland has an impoverished fish fauna (Kelly et al., 2012) and in other ecoregions with more fish species fish effects might be less marked.

\subsection{The influence of trophic interactions}

While the importance of nutrients, particularly TP, in predicting Chla (for example, Phillips et al., 2008) suggests that bottom-up processes are the main determinants of lake status, there is also strong evidence for top-down influences on ecosystem structure in many lakes (for example, Jeppesen et al., 2003; Jones \& Sayer, 2003). Our data provide much evidence of bottom-up but little for top-down effects, a pattern found in cross-lake, correlational, studies such as this one (Leibold et al., 1997). For example, phytoplankton and fish biomasses, and the percentage of predatory fish, increased with TP. Further, contrary to a size-selective predation effect (Hall et al., 1976), the biomass of the larger, Daphnia spp., cladocerans increased with fish and cyprinid biomasses, while small cladocerans declined. Moreover, neither overall zooplankton size nor that of Daphnia varied with fish biomass. The Zoo:Phyto biomass ratio declined with increasing cyprinid biomass, a trend usually interpreted as due to increased zooplanktivory (Jeppesen et al., 2003), but in our lakes this was because of increasing 
phytoplankton, not declining zooplankton, biomass. The weak evidence for top-down effects in our study is probably not a consequence of missing other predators: few invertebrate zooplanktivores were recorded (Chaoborus occurred in only eight lakes) and no effects were found on the biomasses or mean sizes of the zooplankton components. Other cross-lake comparisons indicate that planktivorous fish do reduce zooplankton size, by size-selective predation on large cladocerans (references in Hall et al., 1976; Taylor \& Carter, 1997; Jeppesen et al., 2003) but the strongest evidence for top-down control comes from within-lake studies (McQueen, Post \& Mills, 1986; Leibold et al., 1997) which we did not conduct. zooplanktivory potentially increases phytoplankton biomass by reducing zooplankton grazing pressure and cyprinids can release sediment nutrients when foraging on benthic invertebrates (Vanni, 2002). In our study trophic structure and lake status did vary with cyprinid occurrence. However, the change outlined above in cladoceran sizes with increasing cyprinid biomass is contrary to the usual fish sizeselective predation effect. Bioturbation by cyprinids releases nutrients to the water column, thereby affecting phytoplankton biomass and composition: the loss of the more TP sensitive taxa with increasing Chla supports this second hypothesis. TP increased with the biomass of sediment-feeding roach, bream and tench, consistent with a bioturbation effect. The negative correlations between cyprinid and trout occurrence, and pike and trout biomasses, might indicate competition and predation effects, but equally could result from different environmental preferences for these species. Cyprinids were introduced into Ireland (Champ, Kelly \& King, 2009) so their effect, in part, reflects where they were introduced: the association of cyprinid biomass and zebra mussel occurrence also reflects introduction of the latter. The major effects that both taxa can have on ecosystem structure and function (Winfield \& Townsend, 1991; Maclsaac, 1996; Salgado et al., 2018) strongly argues for recording whether or not such influential introduced species are present when assessing lake status.

While several metrics distinguish between native and introduced species (Kelly et al., 2012; Petriki, Lazaridou \& Bobori, 2017) we demonstrate for the first time that fish have a quantifiable effect on EQRs. Mean EQR scores in lakes with cyprinids were lower than in cyprinid-free lakes below about $10 \mu \mathrm{g} \mathrm{L}-1$ Chla and $40 \mu \mathrm{g} \mathrm{L}-1 \mathrm{TP}$, consistent with cyprinids contributing to eutrophication. Cyprinids in more productive lakes appeared to increase EQRs (Fig. 3b); however, the number of observations for these eutrophic lakes in our study is small. Increased EQRs could also occur from a 
change in phytoplankton composition due to increased zooplankton grazing on phytoplankton, and/or an increase in zooplanktivory. Phytoplankton composition did change with eutrophication and TPtolerant taxa were more abundant in cyprinid lakes, largely because of the loss of the most TPintolerant taxa (Fig. S1).

\section{Conclusions}

EQRs for phytoplankton, macrophytes and fish were positively correlated with each other and much of the variance in mean EQR was accounted for by six, easily measured variables: cyprinid occurrence, Chla, TP, water colour, population density and elevation. Introduced, cyprinid, fish reduced mean EQRs in oligotrophic lakes but this effect decreased in eutrophic lakes, probably from nutrients released from the sediment during benthic feeding. The limited concordance in the responses of BQEs to environmental variables, coupled with evidence showing a cyprinid eutrophication effect on EQRs when using multiple BQEs, strongly supports the importance of adopting a more integrated approach to the assessment of lake quality status. In the spirit of Moss (2007), it should be possible to develop simple, yet robust, relationships to easily assess lake ecological quality that can inform compliance with environmental management objectives by using multiple biotic elements.

\section{Acknowledgements}

We thank two anonymous referees and Prof. Helen Jarvie for their careful and insightful comments on the manuscript. This DOLMANT (Development of targeted ecological modelling tools for Lake Management) project was supported by the European Union's INTERREG IVa Programme, managed by the Special EU Programmes Body (SEUPB). We are also grateful for the assistance provided by the Department of Agriculture, Environment and Rural Affairs, Northern Ireland, Inland Fisheries Ireland and the Irish Environmental Protection Agency.

\section{References}

Arndt, H. (1993) Rotifers as predators on components of the microbial web (bacteria, heterotrophic flagellates, ciliates) - a review. Hydrobiologia, 255, 231-246. doi: 10.1007/BF00025844

Bellinger, E.G. \& Sigee, D.C. (2010) Freshwater algae: identification and use as bioindicators WileyBlackwell, Chichester.

Camargo, J.A. \& Alonso, A. (2006) Ecological and toxicological effects of inorganic nitrogen pollution in aquatic ecosystems: a global assessment. Environ Int, 32, 831-49. doi: 10.1016/j.envint.2006.05.002 
Canter-Lund, H. \& Lund, J.W.G. (1995) Freshwater algae: their microscopic world explored Biopress, Bristol.

Caroni, R., Bund, W., Clarke, R.T., \& Johnson, R.K. (2013) Combination of multiple biological quality elements into waterbody assessment of surface waters. Hydrobiologia, 704, 437-451. doi: 10.1007/s10750-012-1274-y

Caroni, R. \& Irvine, K. (2010) The potential of zooplankton communities for ecological assessment of lakes: redundant concept or political oversight? Biol. Environ., 110, 35-53. doi: 10.3318/bioe.2010.110.1.35

Carpenter, S.R. \& Kitchell, J.F., eds. (1993) The trophic cascade in lakes, pp 385. Cambridge University Press, Cambridge.

Carvalho, L., Miller, C.A., Scott, E.M., Codd, G.A., Davies, P.S., \& Tyler, A.N. (2011) Cyanobacterial blooms: statistical models describing risk factors for national-scale lake assessment and lake management. Sci. Total Environ., 409, 5353-5358. doi: 10.1016/j.scitotenv.2011.09.030

CEN (2005) Water quality - Sampling of fish with multi-mesh gill nets. In CEN EN 14757.

CEN (2006) Water quality - Guidance standard on the enumeration of phytoplankton using inverted microscopy (Utermöhl technique). In CEN EN 15204.

Champ, W.S.T., Kelly, F.L., \& King, J.J. (2009) The Water Framework Directive: using fish as a management tool. Biol. Environ., 109B, 191-206. doi: 10.3318/bioe.2009.109.3.191

Chapman, B., Cokke, G.H., \& Whitehead, R. (1967) Automated analysis: the determination of ammonical, nitrous and nitric nitrogen in river waters, sewage effluents and trade effluents. Water Pollut. Control, 77, 478-491.

Chow-Fraser, P. (1991) Use of the morphoedaphic index to predict nutrient status and algal biomass in some Canadian lakes. Can. J. Fish. Aquat. Sci., 48, 1909-1918. doi: 10.1139/f91-227

Cox, E.J. (1996) The identification of freshwater diatoms from live material Chapman and Hall, London.

Downing, J.A. \& McCauley, E. (1992) The nitrogen:phosphorus relationship in lakes. Limnol. Oceanogr., 37, 936-945. doi: 10.4319/lo.1992.37.5.0936

Downing, J.A. \& Rigler, F.H., eds. (1984) A manual on methods for the assessment of secondary productivity in fresh waters, pp 500. Blackwell Science, Oxford.

Eisenreich, S.J., Bannerman, R.T., \& Armstrong, D.E. (1975) A simplified phosphorus analysis technique. Environ. Lett., 9, 43-53. doi: 10.1080/00139307509437455

Elith, J., Leathwick, J.R., \& Hastie, T. (2008) A working guide to boosted regression trees. J. Anim. Ecol., 77, 802-813. doi: 10.1111/j.1365-2656.2008.01390.x

Free, G., Tierney, D., Little, R., Kelly, F.L., Kennedy, B., Plant, C., Trodd, W., Wynne, C., Caroni, R., \& Byrne, C. (2016) Lake ecological assessment metrics in Ireland: relationships with phosphorus and typology parameters and the implications for setting nutrient standards. Biol. Environ., 116B, 191-204. doi: 10.3318/bioe.2016.18

Golterman, H.L., Clymo, R.S., \& Ohnstad, M.A.N. (1978) Methods for the physical and chemical analysis of freshwaters Blackwell Scientific Publications, Oxford.

Hall, D.J., Threlkeld, S.T., Burns, C.W., \& Crowley, P.H. (1976) The size-efficiency hypothesis and the size structure of zooplankton communities. Annu. Rev. Ecol. Syst., 7, 177-208. doi: 10.1146/annurev.es.07.110176.001141

Harding, J.P. \& Smith, W.A. (1974) A key to the British freshwater cyclopid and calanoid copepods, 2nd edn. Freshwater Biological Association.

Heegaard, E., Birks, H.H., Gibson, C.E., Smith, S.J., \& Wolfe-Murphy, S. (2001) Speciesenvironmental relationships of aquatic macrophytes in Northern Ireland. Aquat. Bot., 70, 175223. doi: 10.1016/S0304-3770(01)00161-9

Hijmans, R.J., Phillips, S., Leathwick, J., \& Elith, J. (2016) dismo: species distribution modeling. R package version 1.0-15.

Hill, M.O., Preston, C.D., \& Smith, A.J.E. (1991-4) Atlas of the bryophytes of Britain and Ireland Harley Books, Colchester.

Järvinen, M., Drakare, S., Free, G., Lyche-Solheim, A., Phillips, G., Skjelbred, B., Mischke, U., Ott, I., Poikane, S., Søndergaard, M., Pasztaleniec, A., Van Wichelen, J., \& Portielje, R. (2012) Phytoplankton indicator taxa for reference conditions in Northern and Central European lowland lakes. Hydrobiologia, 704, 97-113. doi: 10.1007/s10750-012-1315-6

Jeppesen, E., Jensen, J.P., Jensen, C., Faafeng, B., Hessen, D.O., Søndergaard, M., Lauridsen, T., Brettum, P., \& Christoffersen, K. (2003) The impact of nutrient state and lake depth on topdown control in the pelagic zone of lakes: a study of 466 lakes from the temperate zone to the Arctic. Ecosystems, 6, 313-325. doi: 10.1007/PL00021503 
Jeppesen, E., Jensen, J.P., Søndergaard, M., Lauridsen, T., Pedersen, L.J., \& Jensen, L. (1997) Topdown control in freshwater lakes: the role of nutrient state, submerged macrophytes and water depth. Hydrobiologia, 342/343, 151-164. doi: 10.1023/A:1017046130329

Jeppesen, E., Jensen, J.P., Søndergaard, M., Lauridsen, T.L., \& Landkildhus, F. (2000) Trophic structure, species richness and biodiversity in Danish lakes: changes along a phosphorus gradient. Freshwater Biol. , 45, 201-218. doi: 10.1046/j.1365-2427.2000.00675.x

Jeppesen, E., Nõges, P., Davidson, T.A., Haberman, J., Nõges, T., Blank, K., Lauridsen, T.L., Søndergaard, M., Sayer, C., Laugaste, R., Johansson, L.S., Bjerring, R., \& Amsinck, S.L. (2011) Zooplankton as indicators in lakes: a scientific-based plea for including zooplankton in the ecological quality assessment of lakes according to the European Water Framework Directive (WFD). Hydrobiologia 676, 279-297. doi: 10.1007/s10750-011-0831-0

John, D.M., Whitton, B.A., \& Brook, A.J., eds. (2011) The freshwater algal flora of the British Isles: an identification guide to freshwater and terrestrial algae. Cambridge University Press, Cambridge.

Jones, J.I. \& Sayer, C.D. (2003) Does the fish-invertebrate-periphyton cascade precipitate plant loss in shallow lakes? Ecology, 84, 2155-2167. doi: 10.1890/02-0422

Kelly, F.L., Champ, W.S.T., Harrison, A., Connor, L., \& Rosell, R. (2008) A lake fish stock survey method for the Water Framework Directive. In Proceedings of the 38th Annual IFM Conference - Fish stocks and their Environment (eds C. Moriarty, R. Rosell \& P. Gargan), Westport, Co. Mayo, Ireland.

Kelly, F.L., Harrison, A.J., Allen, M., Connor, L., \& Rosell, R. (2012) Development and application of an ecological classification tool for fish in lakes in Ireland. Ecol. Indic., 18, 608-619. doi: 10.1016/j.ecolind.2012.01.028

Kelly, M.G. (2000) Identification of common benthic diatoms in rivers. Field Studies Council Publication, 9, 583-700.

Kelly, M.G., Birk, S., Willby, N.J., Denys, L., Drakare, S., Kahlert, M., Karjalainen, S.M., Marchetto, A., Pitt, J.A., Urbanic, G., \& Poikane, S. (2016) Redundancy in the ecological assessment of lakes: are phytoplankton, macrophytes and phytobenthos all necessary? Sci. Total Environ., 568, 594-602. doi: 10.1016/j.scitotenv.2016.02.024

Komárek, J. (1999) Übersicht der planktischen blaualgen (cyanobakterien) im einzugsgebiet der Elbe. In Internationale Kommission zum Schutz der Elbe.

Komárek, J. \& Anagnostidis, K. (1999) Cyanoprokaryota: Chroococcales. In Süsswasserflora von Mitteleuropa, Vol. 19, Part 1. Springer.

Komárek, J. \& Anagnostidis, K. (2007) Cyanoprokaryota: Oscillatoriales. In Süsswasserflora von Mitteleuropa, Vol. 19, Part 2. Springer.

Leibold, M.A., Chase, J.M., Shurin, J.B., \& Downing, A.L. (1997) Species turnover and the regulation of trophic structure. Annu. Rev. Ecol. Syst., 28, 467-494. doi: 10.1146/annurev.ecolsys.28.1.467

Lyche-Solheim, A., Feld, C.K., Birk, S., Phillips, G., Carvalho, L., Morabito, G., Mischke, U., Willby, N., Søndergaard, M., Hellsten, S., Kolada, A., Mjelde, M., Böhmer, J., Miler, O., Pusch, M.T., Argillier, C., Jeppesen, E., Lauridsen, T.L., \& Poikane, S. (2013) Ecological status assessment of European lakes: a comparison of metrics for phytoplankton, macrophytes, benthic invertebrates and fish. Hydrobiologia, 704, 57-74. doi: 10.1007/s10750-012-1436-y

Maclsaac, H.J. (1996) Potential abiotic and biotic impacts of zebra mussels on the inland waters of North America. Am. Zool. , 36, 287-299. doi: 10.1093/icb/36.3.287

Marker, A.F.H., Crowther, C.A., \& Gunn, R.J.M. (1980) Methanol and acetone as solvents for estimating chlorophyll $a$ and phaeopigments by spectrophotometry. Erg. Limnol., 14, 52-69.

McQueen, D.J., Post, J.R., \& Mills, E.L. (1986) Trophic relationships in freshwater pelagic ecosystems. Canadian Journal of Fisheries \& Aquatic Sciences, 43, 1571-1581. doi: 10.1139/f86-195

Mischke, U., Thackeray, S., Dunbar, M., McDonald, C., Carvalho, L., De Hoyos, C., Jarvinen, M., Laplace-Treyture, C., Morabito, G., Skjelbred, B., Lyche Solheim, A., Brierley, B., \& Dudley, B. (2012) Guidance document on sampling, analysis and counting standards for phytoplankton in lakes.

Moore, J.A. (1986) Charophytes of Great Britain and Ireland Botanical Society of the British Isles, London.

Moss, B. (1998) Ecology of fresh waters, 3rd edn. Blackwell Science, Oxford.

Moss, B. (2007) Shallow lakes, the water framework directive and life. What should it all be about? Hydrobiologia, 584, 381-394. doi: 10.1007/s10750-007-0601-1 
Moss, B. (2008) The Water Framework Directive: total environment or political compromise? Sci. Total Environ., 400, 32-41. doi: 10.1016/j.scitotenv.2008.04.029

Nürnberg, G.K. \& Shaw, M. (1999) Productivity of clear and humic lakes: nutrients, phytoplankton, bacteria. Hydrobiologia, 382, 97-112. doi: 10.1023/A:1003445406964

Olin, M., Rask, M., Ruuhijärvi, J., Kurkilahti, M., Ala-Opas, P., \& Ylönens, O. (2002) Fish community structure in mesotrophic and eutrophic lakes of southern Finland: the relative abundances of percids and cyprinids along a trophic gradient. J. Fish. Biol., 60, 593-612. doi: 10.1006/jfbi.2002.1876

Persson, L., Diehl, S., Johansson, L., Andersson, G., \& Hamrin, S.F. (1991) Shifts in fish communities along the productivity gradient of temperate lakes - patterns and the importance of sizestructured interactions. J. Fish. Biol., 38, 281-294. doi: 10.1111/j.1095-8649.1991.tb03114.x

Petriki, O., Lazaridou, M., \& Bobori, D.C. (2017) A fish-based index for the assessment of the ecological quality of temperate lakes. Ecol. Indic., 78, 556-565. doi: 10.1016/j.ecolind.2017.03.029

Phillips, G., Pietiläinen, O.P., Carvalho, L., Solimini, A., Lyche Solheim, A., \& Cardoso, A.C. (2008) Chlorophyll-nutrient relationships of different lake types using a large European dataset. Aquat. Ecol., 42, 213-226. doi: 10.1007/s10452-008-9180-0

Poikane, S., Birk, S., Böhmer, J., Carvalho, L., de Hoyos, C., Gassner, H., Hellsten, S., Kelly, M., Lyche Solheim, A., Olin, M., Pall, K., Phillips, G., Portielje, R., Ritterbusch, D., Sandin, L., Schartau, A.-K., Solimini, A.G., van den Berg, M., Wolfram, G., \& van de Bund, W. (2015) A hitchhiker's guide to European lake ecological assessment and intercalibration. Ecol. Indic., 52, 533-544. doi: 10.1016/j.ecolind.2015.01.005

Preston, C.D. (1995) Pondweeds of Great Britain and Ireland (BSBI Handbook No.8) Botanical Society of the British Isles, London.

Preston, C.D. \& Croft, J.M. (1997) Aquatic Plants in Britain and Ireland Harley Books, Colchester. R Development Core Team (2014) R: A language and environment for statistical computing. R Foundation for Statistical Computing, Vienna, Austria.

Rask, M., Vuori, K.-M., Hämäläinen, H., Järvinen, M., Hellsten, S., Mykrä, H., Arvola, L., Ruuhijärvi, J., Jyväsjärvi, J., Kolari, I., Olin, M., Salonen, E., \& Valkeajärvi, P. (2011) Ecological classification of large lakes in Finland: comparison of classification approaches using multiple quality elements. Hydrobiologia, 660, 37-47. doi: 10.1007/s10750-010-0384-7

Reynolds, C.S. (2006) The ecology of phytoplankton Cambridge University Press, Cambridge.

Ridgeway, G. (2015) Generalized boosted regression models. R package version 2.1.1.

Rose, F. (1981) The wild flower key Penguin, London.

Salgado, J., Sayer, C.D., Brooks, S.J., Davidson, T.A., Goldsmith, B., Patmore, I.R., Baker, A.G., \& Okamura, B. (2018) Eutrophication homogenizes shallow lake macrophyte assemblages over space and time. Ecosphere, 9, e02406. doi: 10.1002/ecs2.2406

Scheffer, M. (1998) Ecology of shallow lakes Chapman \& Hall, London.

Scheffer, M. \& van Nes, E.H. (2007) Shallow lakes theory revisited: various alternative regimes driven by climate, nutrients, depth and lake size. Hydrobiologia, 584, 455-466. doi: 10.1007/s10750007-0616-7

Scheiner, D. (1976) Determination of ammonia and Kjeldahl nitrogen by indophenol blue method. Water Res., 10, 31-36. doi: 10.1016/0043-1354(76)90154-8

Scourfield, D.J. \& Harding, J.P. (1966) A key to the British species of freshwater Cladocera Freshwater Biological Association.

Smith, V.H. (2003) Eutrophication of freshwater and coastal marine ecosystems: a global problem. Environ. Sci. Pollut. R., 10, 126-139. doi: 10.1065/espr2002.12.142

Standing Committee of Analysts (1979) The measurement of electrical conductivity and the laboratory determination of the $\mathrm{pH}$ value of natural, treated and waste waters. In Methods for the examination of waters and associated materials. HMSO, London.

Standing Committee of Analysts (1982) The determination of alkalinity and acidity in water 1981. In Methods for the examination of waters and associated materials. HMSO, London.

Standing Committee of Analysts (1984) Colour and turbidity of waters 1981. In Methods for the examination of waters and associated materials. HMSO, London.

Sterner, R.W. \& Elser, J.J. (2002) Ecological stoichiometry: the biology of elements from molecules to the biosphere Princeton University Press, Princeton.

Taylor, W.D. \& Carter, J.C.H. (1997) Zooplankton size and its relationship to trophic status in deep Ontario lakes. Can. J. Fish. Aquat. Sci., 54, 2691-2699. doi: 10.1139/f97-166 
UKTAG (2008) UKTAG lakes assessment methods: macrophytes and phytobenthos. Macrophytes (Free index), pp. 12. Water Framework Directive - United Kingdom Technical Advisory Group, Edinburgh.

UKTAG (2014) UKTAG guide to phytoplankton in lakes: Phytoplankton Classification with Uncertainty Tool (PLUTO), pp. 53. Water Framework Directive - United Kingdom Advisory Group, Stirling. Vanni, M.J. (2002) Nutrient cycling by animals in freshwater ecosystems. Annu. Rev. Ecol. Syst., 33, 341-370.

Voulvoulis, N., Arpon, K.D., \& Giakoumis, T. (2017) The EU Water Framework Directive: from great expectations to problems with implementation. Sci. Total Environ., 575, 358-366. doi: 10.1016/j.scitotenv.2016.09.228

Winfield, I.J. \& Townsend, C.R. (1991). The role of cyprinids in ecosystems. In Cyprinid fishes: systematics, biology and exploitation (eds I.J. Winfield \& J.S. Nelson), pp. 552-571. Chapman \& Hall, London. 
687 Table 1. PCA of environmental variables for the study lakes showing varimax rotated component 688 loadings for factors with eigenvalues $>1$. Correlations between the environmental variables and West689 East (rWE) and South-North (rSN) lake spatial position are also shown.

690

\begin{tabular}{|c|c|c|c|c|c|}
\hline Variable & Factor 1 & Factor 2 & Factor 3 & $r W E$ & $r S N$ \\
\hline Morphoedaphic index (MEI) & $0.892^{\star * *}$ & -0.007 & 0.109 & $0.409^{* * *}$ & $-0.484^{* * *}$ \\
\hline $\mathrm{pH}$ & $0.861^{* * *}$ & 0.207 & 0.178 & $0.457^{* * *}$ & $-0.373^{* *}$ \\
\hline Silicate $\left(\mathrm{SiO}_{2}\right)$ & $0.790^{* * *}$ & 0.295 & 0.074 & $0.386^{* *}$ & $-0.308^{*}$ \\
\hline Total phosphorus (TP) & $0.759 * * *$ & 0.042 & -0.269 & $0.389^{* *}$ & $-0.455^{* * *}$ \\
\hline Population density & $0.542^{* * *}$ & $0.402^{\star *}$ & $0.447^{* * *}$ & $0.279^{*}$ & -0.135 \\
\hline Ammoniacal nitrogen $\left(\mathrm{NH}_{4} \mathrm{~N}\right)$ & $0.315^{\star}$ & $0.613^{\star * *}$ & -0.263 & 0.057 & -0.215 \\
\hline Total oxidised nitrogen (TON) & 0.212 & $0.493^{* * *}$ & 0.230 & $0.433^{* *}$ & -0.242 \\
\hline Chloride & 0.047 & -0.199 & $0.820^{* * *}$ & 0.252 & $0.429^{* *}$ \\
\hline Elevation & -0.107 & $-0.383^{* *}$ & $-0.713^{* * *}$ & 0.074 & -0.153 \\
\hline Area & -0.211 & $0.872^{* * *}$ & 0.016 & $-0.352^{*}$ & 0.093 \\
\hline Water colour & $-0.616^{\star * *}$ & 0.137 & $-0.312^{*}$ & $-0.560 * * *$ & 0.102 \\
\hline$\%$ variance explained & 32.8 & 17.1 & 15.7 & & \\
\hline
\end{tabular}


692 Table 2. Boosted regression tree relative influence values (\%) across taxa. Signs have been added to 693 these values, to indicate whether biomass increases or decreases (-) with the environmental variable. 694

\begin{tabular}{|c|c|c|c|c|c|c|c|c|}
\hline & \multicolumn{4}{|c|}{ Biomass } & \multicolumn{4}{|c|}{$E Q R$} \\
\hline & Phyto & Macro & Zoo & Fish & Phyto & Macro & Fish & Mean \\
\hline TP & 37.8 & -5.8 & 5.2 & 20.2 & -35.2 & -56.7 & -5.7 & -31.5 \\
\hline $\mathrm{pH}$ & 19.0 & 1.7 & -3.8 & 10.4 & -11.7 & -4.2 & -3.8 & -12.2 \\
\hline Colour & -9.6 & -2.9 & -44.9 & -3.0 & 5.6 & -8.1 & -1.0 & -3.2 \\
\hline TON & 2.2 & -3.0 & 0.5 & 2.7 & -4.4 & 1.2 & -2.7 & -3.6 \\
\hline $\mathrm{NH}_{4} \mathrm{~N}$ & -3.1 & 1.1 & 0.8 & 18.1 & -2.7 & -1.4 & -2.2 & -2.5 \\
\hline $\mathrm{Cl}$ & 5.5 & 3.3 & 2.6 & -2.8 & -9.3 & 1.3 & 3.1 & -4.5 \\
\hline $\mathrm{SiO}_{2}$ & -6.6 & -0.7 & -27.6 & 13.5 & 8.4 & -5.3 & -1.0 & 1.8 \\
\hline Area & 2.0 & -3.0 & -3.4 & 10.2 & 2.4 & -2.1 & 2.6 & 4.9 \\
\hline Elevation & 6.2 & -18.3 & 3.7 & -5.1 & -11.0 & -3.5 & -4.0 & -6.4 \\
\hline Population density & -4.6 & 33.8 & 6.8 & 2.0 & 7.7 & -7.5 & -34.9 & -13.4 \\
\hline MEI & 3.4 & 26.5 & 0.8 & 12.0 & 1.6 & -8.7 & -39.1 & -16.1 \\
\hline Pseudo $R^{2}(\%)$ & 88 & 32 & 99 & 58 & 80 & 82 & 60 & 91 \\
\hline
\end{tabular}

695 
Table 3. Correlations between EQR scores and taxon biomass and spatial position.

697

\begin{tabular}{|c|c|c|c|c|}
\hline & EQR Phyto & EQR Macro & EQR Fish & Mean EQR \\
\hline Chla & $-0.825^{\star \star *}$ & $-0.649^{\star \star *}$ & $-0.434^{* *}$ & $-0.767^{* * *}$ \\
\hline Phytoplankton & $-0.819^{* * *}$ & $-0.602^{* * *}$ & $-0.322^{*}$ & $-0.688^{* * *}$ \\
\hline Cyanophytes & $-0.699^{* * *}$ & $-0.514^{\star * *}$ & $-0.279^{*}$ & $-0.589^{\star * *}$ \\
\hline Macrophytes & $0.362^{* *}$ & 0.087 & -0.231 & 0.038 \\
\hline Zooplankton & -0.142 & -0.152 & -0.028 & -0.121 \\
\hline Fish & -0.153 & $-0.414^{* *}$ & $-0.648^{* * *}$ & $-0.557^{* * *}$ \\
\hline WE position & $-0.651^{* * *}$ & $-0.360^{* *}$ & $-0.418^{* *}$ & $-0.593^{* * *}$ \\
\hline SN position & $0.353^{*}$ & $0.545^{\star * *}$ & $0.458^{* * *}$ & $0.569^{* * *}$ \\
\hline
\end{tabular}

698

${ }^{* \star *} P<0.001,{ }^{* *} P<0.01,{ }^{*} P<0.05$ 
Table 4. Multiple linear regression environmental predictors of mean EQR.

700

\begin{tabular}{llll}
\hline & Regression coefficient & Standardised coefficient & $t$ \\
\hline Intercept & $1.535 \pm 0.129$ & & $11.88^{* * *}$ \\
Cyprinid presence(1)/absence(0) & $-0.141 \pm 0.028$ & -0.395 & $4.96^{* * *}$ \\
TP & $-0.326 \pm 0.051$ & -0.588 & $6.44^{* * *}$ \\
Chla:TP ratio & $-0.233 \pm 0.046$ & -0.408 & $5.04^{* * *}$ \\
PopDen & $-0.043 \pm 0.016$ & -0.222 & $2.74^{* *}$ \\
Water colour & $-0.151 \pm 0.055$ & -0.232 & $2.74^{* *}$ \\
Elevation & $-0.008 \pm 0.004$ & -0.155 & $2.04^{*}$
\end{tabular}


702 Table 5. Correlations between trophic level biomass ratios, \% piscivorous fish biomass and the 703 environmental variables.

704

\begin{tabular}{|c|c|c|c|c|c|}
\hline & Phyto:TP & Macro:Phyto & Zoo:Phyto & Fish:Zoo & $\%$ piscivorous fish \\
\hline TP & 0.115 & $-0.510^{* \star *}$ & $-0.436^{* *}$ & 0.155 & $0.390^{\star *}$ \\
\hline $\mathrm{pH}$ & 0.223 & $-0.315^{\star}$ & $-0.481^{* * *}$ & $0.403^{* *}$ & $0.379^{* *}$ \\
\hline Colour & $-0.366^{* *}$ & 0.269 & 0.270 & 0.041 & $-0.335^{*}$ \\
\hline TON & 0.150 & -0.200 & -0.204 & 0.284 & 0.193 \\
\hline $\mathrm{NH}_{4} \mathrm{~N}$ & -0.181 & 0.048 & 0.159 & 0.219 & 0.146 \\
\hline $\mathrm{Cl}$ & 0.192 & 0.052 & -0.056 & -0.207 & 0.163 \\
\hline $\mathrm{SiO}_{2}$ & 0.057 & -0.131 & -0.240 & $0.353^{*}$ & $0.335^{*}$ \\
\hline Area & -0.253 & 0.169 & $0.286^{*}$ & 0.097 & -0.087 \\
\hline Elevation & 0.127 & -0.258 & -0.077 & -0.267 & 0.047 \\
\hline Population density & -0.134 & 0.131 & 0.025 & 0.168 & $0.305^{*}$ \\
\hline MEI & 0.172 & -0.179 & $-0.379 * *$ & $0.325^{*}$ & $0.291^{*}$ \\
\hline
\end{tabular}


Table 6. Correlations between zooplankton biomass and mean body mass and Chla, phytoplankton

707 and cyanophyte, total fish and cyprinid biomasses.

708

\begin{tabular}{|c|c|c|c|c|c|}
\hline & Chla & Phytoplankton & Cyanophyte & Fish & Cyprinid \\
\hline \multicolumn{6}{|l|}{ Biomass } \\
\hline All species & 0.202 & 0.256 & 0.270 & 0.122 & -0.042 \\
\hline Daphnia & 0.153 & 0.166 & 0.238 & $0.457^{* * *}$ & 0.214 \\
\hline Other grazer cladocerans $†$ & -0.275 & -0.174 & -0.270 & $-0.337^{*}$ & $-0.420^{* *}$ \\
\hline Predatory cladocerans & -0.159 & 0.115 & -0.002 & -0.020 & -0.137 \\
\hline Small cladocerans $\ddagger$ & -0.202 & -0.090 & -0.196 & -0.281 & $-0.418^{* *}$ \\
\hline Cyclopoid copepods & 0.124 & 0.059 & 0.088 & 0.224 & 0.092 \\
\hline Calanoid copepods & -0.147 & -0.115 & 0.060 & -0.267 & $-0.410^{* *}$ \\
\hline \% Daphnia & 0.261 & 0.217 & 0.188 & $0.440^{* *}$ & $0.353^{*}$ \\
\hline \multicolumn{6}{|l|}{ Mean mass } \\
\hline All species & 0.050 & 0.080 & 0.047 & 0.067 & 0.091 \\
\hline Daphnia & -0.050 & 0.002 & 0.078 & -0.007 & 0.043 \\
\hline Other grazer cladocerans $†$ & $-0.341^{*}$ & $-0.295^{\star}$ & $-0.308^{*}$ & -0.120 & -0.293 \\
\hline Predatory cladocerans & -0.010 & 0.103 & 0.100 & -0.288 & -0.312 \\
\hline Small cladocerans $\ddagger$ & -0.253 & -0.193 & -0.250 & 0.082 & $-0.342^{*}$ \\
\hline Cyclopoid copepods & -0.064 & -0.072 & 0.034 & 0.053 & 0.040 \\
\hline Calanoid copepods & 0.147 & 0.196 & -0.002 & -0.095 & -0.112 \\
\hline
\end{tabular}

709 *** $P<0.001,{ }^{* *} P<0.01,{ }^{*} P \leq 0.05$

710 † Other grazer cladocerans: Bosmina, Ceriodaphnia, Diaphanosoma, Eurycercus, Holopedium, Sida

711 ‡ Small cladocerans: Bosmina, Ceriodaphnia, Diaphanosoma 


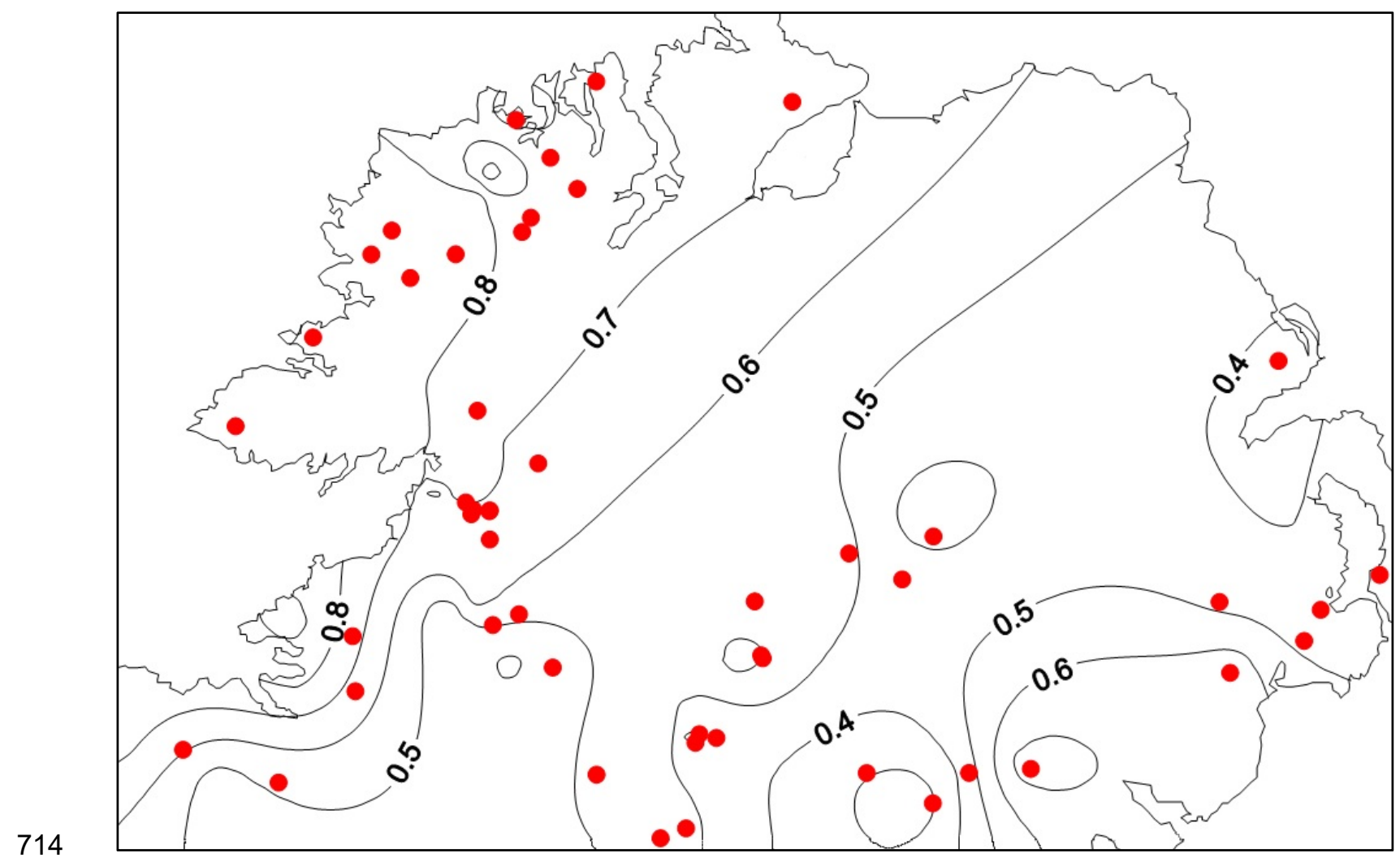

715

716 Fig. 1. Lake locations and trends in mean ecological quality ratio (EQR) scores. Contours were drawn 717 using Surfer® 8 (Golden Software, LLC). 


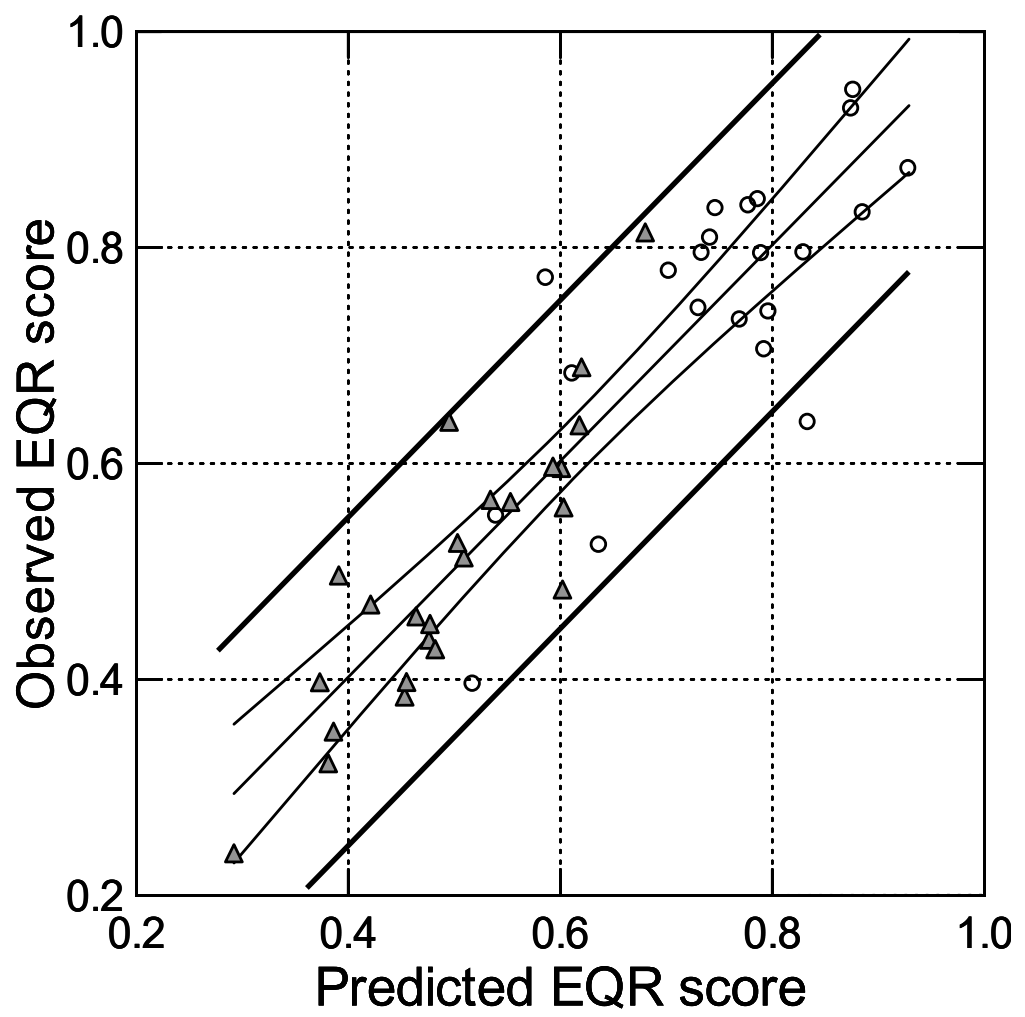

731

732 Fig. 2. Observed mean lake ecological quality ratio $(E Q R)$ as a function of predicted mean $E Q R$ in 733 cyprinid (triangles) and cyprinid-free (circles) lakes. The 95\% confidence and prediction limits are 734 shown. 
736

737

738

739

740

741

742

743

744

745

746

747

748

749
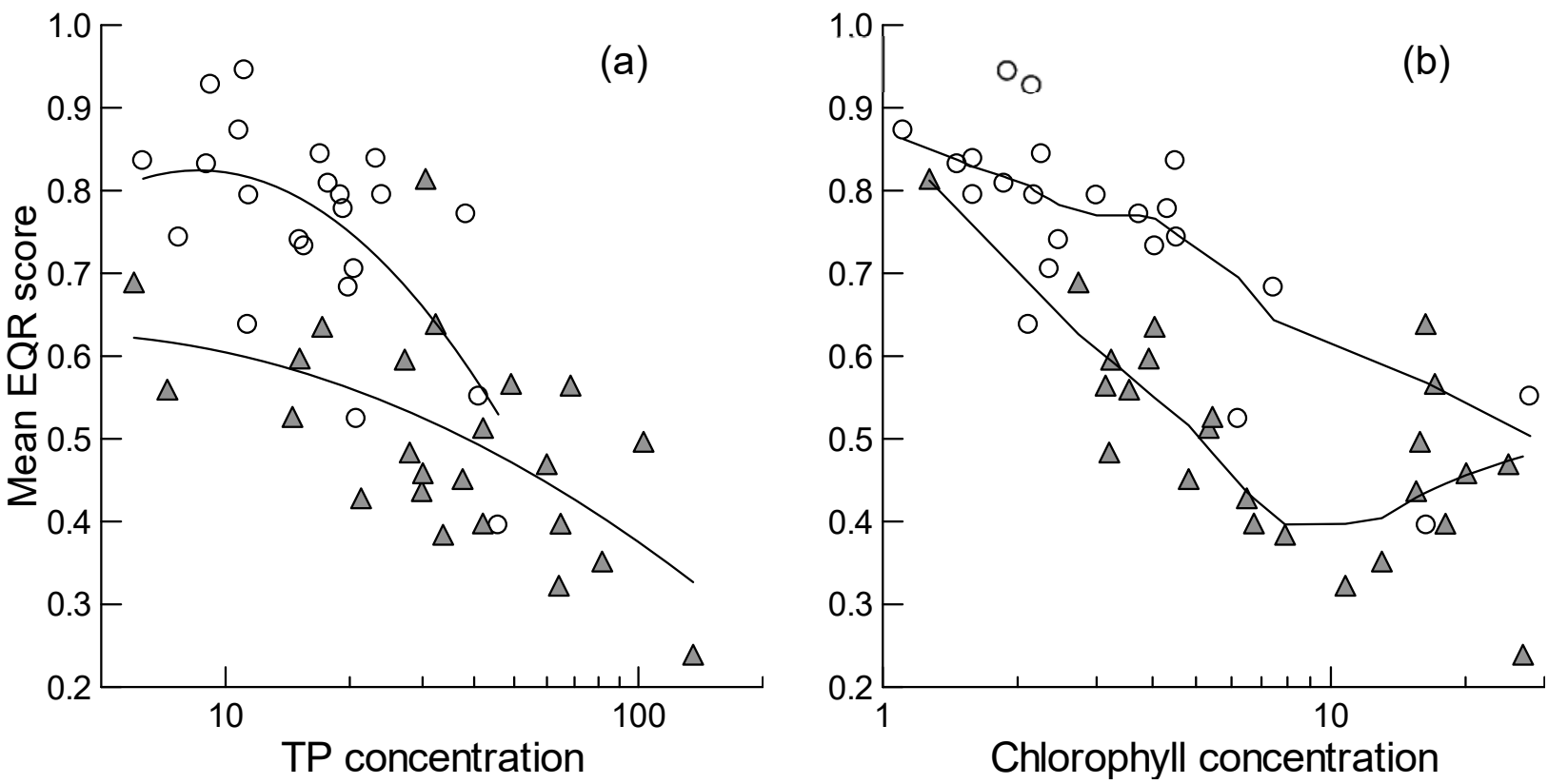

Fig. 3. Mean ecological quality ratio (EQR) scores as a function of (a) total phosphorus (TP) $\left(\mu \mathrm{L} \mathrm{L}^{-1}\right)$ and (b) Chla concentrations in lakes with (triangles) and without (circles) cyprinid fish. Lowess smoothed lines (tension 0.5) are shown in (b). 
752 Table S1. (a) Descriptive statistics for the environmental variables, BQEs and EQRs and (b) Pearson correlation matrix between, the environmental variables.

$755 \quad(a)$

\begin{tabular}{|c|c|c|c|}
\hline & Median & Minimum & Maximum \\
\hline Chla $\left(\mu \mathrm{g} \mathrm{L}^{-1}\right)$ & 4.6 & 0.8 & 46.3 \\
\hline $\operatorname{TP}\left(\mu \mathrm{g} \mathrm{L}^{-1}\right)$ & 22.2 & 5.6 & 149.6 \\
\hline $\mathrm{pH}$ & 7.08 & 5.10 & 8.53 \\
\hline Colour (mg L-1 Pt) & 52.1 & 10.6 & 195.9 \\
\hline TON $\left(\mathrm{mg} \mathrm{L}^{-1}\right)$ & 0.049 & 0.016 & 0.498 \\
\hline $\mathrm{NH}_{4} \mathrm{~N}\left(\mu \mathrm{g} \mathrm{L}^{-1}\right)$ & 10.96 & 0.54 & 48.75 \\
\hline Chloride $\left(\mathrm{mg} \mathrm{L}^{-1}\right)$ & 14.76 & 5.75 & 44.77 \\
\hline $\mathrm{SiO}_{2}\left(\mathrm{mg} \mathrm{L}^{-1}\right)$ & 0.84 & 0.08 & 7.19 \\
\hline Area (ha) & 39.3 & 4.4 & 1399.6 \\
\hline Elevation (masl) & 73 & 5 & 280 \\
\hline Population density (individuals ha-1) & 0.142 & 0.002 & 3.690 \\
\hline $\operatorname{MEI}\left(\mathrm{mg} \mathrm{L}^{-1} \mathrm{~m}^{-1}\right)$ & 0.16 & 0.01 & 3.93 \\
\hline Mean depth $(m)$ & 4.0 & 1.0 & 11.9 \\
\hline Secchi depth $(m)$ & 1.8 & 0.9 & 4.4 \\
\hline $\mathrm{N}: \mathrm{P}$ ratio (mass) & 2.9 & 0.2 & 21.5 \\
\hline$\%$ agricultural land & 36 & 0 & 100 \\
\hline Phytoplankton biomass $\left(\mathrm{mm}^{3} \mathrm{~L}^{-1}\right)$ & 0.56 & 0.05 & 12.59 \\
\hline Cyanophyte biomass $\left(\mathrm{mm}^{3} \mathrm{~L}^{-1}\right)$ & 0.11 & 0.01 & 3.78 \\
\hline Zooplankton biomass ( $\mu \mathrm{g} \mathrm{DW} \mathrm{L^{-1 } )}$ & 77.0 & 10.9 & 654.5 \\
\hline Fish biomass ( $\left.\mathrm{g} \mathrm{m}^{-1} \mathrm{net}\right)$ & 47.6 & 2.3 & 224.8 \\
\hline Phytoplankton species & 29 & 13 & 42 \\
\hline Macrophyte species & 14 & 3 & 40 \\
\hline Zooplankton species & 8 & 3 & 11 \\
\hline Fish species & 4 & 1 & 7 \\
\hline Phytoplankton EQR & 0.83 & 0.43 & 1.18 \\
\hline Macrophytes EQR & 0.67 & 0.21 & 0.96 \\
\hline Fish EQR & 0.39 & 0.01 & 1.00 \\
\hline
\end{tabular}


$757 \quad$ (b)

\begin{tabular}{|c|c|c|c|c|c|c|c|c|c|c|c|c|c|c|}
\hline & TP & $\mathrm{pH}$ & Colour & TON & $\mathrm{NH}_{4} \mathrm{~N}$ & Chloride & $\mathrm{SiO}_{2}$ & Area & Elevation & PopDen & MEI & Alkal & Mean Z & \%agriculture \\
\hline TP & 1 & & & & & & & & & & & & & \\
\hline $\mathrm{pH}$ & $\underline{0.600}$ & 1 & & & & & & & & & & & & \\
\hline Colour & -0.243 & $\underline{-0.509}$ & 1 & & & & & & & & & & & \\
\hline TON & 0.105 & 0.239 & -0.137 & 1 & & & & & & & & & & \\
\hline $\mathrm{NH}_{4} \mathrm{~N}$ & $\underline{0.297}$ & $\underline{0.400}$ & -0.065 & 0.112 & 1 & & & & & & & & & \\
\hline Chloride & -0.061 & 0.159 & -0.250 & 0.040 & -0.111 & 1 & & & & & & & & \\
\hline $\mathrm{SiO}_{2}$ & $\underline{0.435}$ & $\underline{0.692}$ & $\underline{-0.525}$ & $\underline{0.369}$ & $\underline{0.323}$ & -0.018 & 1 & & & & & & & \\
\hline Area & -0.073 & 0.008 & 0.123 & 0.247 & $\underline{0.355}$ & -0.157 & 0.091 & 1 & & & & & & \\
\hline Elevation & 0.053 & $\underline{-0.381}$ & 0.129 & -0.209 & -0.091 & $\underline{-0.382}$ & -0.207 & -0.276 & 1 & & & & & \\
\hline PopDen & $\underline{0.331}$ & $\underline{0.512}$ & $\underline{-0.333}$ & $\underline{0.365}$ & 0.233 & $\underline{0.303}$ & $\underline{0.539}$ & 0.248 & $\underline{-0.392}$ & 1 & & & & \\
\hline MEI & $\underline{0.601}$ & $\underline{0.773}$ & $\underline{-0.429}$ & 0.204 & 0.172 & 0.051 & $\underline{0.670}$ & -0.208 & -0.245 & $\underline{0.564}$ & 1 & & & \\
\hline Alkalinity & $\underline{0.558}$ & $\underline{0.854}$ & $\underline{-0.567}$ & $\underline{0.358}$ & 0.227 & 0.065 & $\underline{0.768}$ & -0.040 & $\underline{-0.350}$ & $\underline{0.627}$ & $\underline{0.908}$ & 1 & & \\
\hline Mean Z & -0.242 & -0.029 & -0.200 & 0.277 & 0.044 & 0.004 & 0.072 & $\underline{0.342}$ & -0.136 & -0.022 & $\underline{-0.437}$ & -0.032 & 1 & \\
\hline$\%$ agriculture & $\underline{0.550}$ & $\underline{0.551}$ & $\underline{-0.289}$ & $\underline{0.397}$ & 0.130 & 0.002 & $\underline{0.429}$ & 0.014 & -0.080 & $\underline{0.441}$ & $\underline{0.541}$ & $\underline{0.591}$ & -0.009 & 1 \\
\hline
\end{tabular}

758 Underlined coefficients $P<0.05$ 
759 Table S2. Correlations (Pearson $r$ ) between phytoplankton, macrophytes, zooplankton and fish biomasses and the environmental variables.

\begin{tabular}{|c|c|c|c|c|c|c|c|c|c|c|c|c|c|}
\hline & \multicolumn{4}{|c|}{ Phytoplankton } & \multirow[t]{2}{*}{ Macrophytes } & \multicolumn{4}{|c|}{ Zooplankton } & \multicolumn{4}{|c|}{ Fish } \\
\hline & Chla & Total & Cyanophytes & $\begin{array}{l}\text { Other } \\
\text { phytoplankton }\end{array}$ & & Total & Daphnia & $\begin{array}{l}\text { Other } \\
\text { Cladocera }\end{array}$ & Copepods & Total & Cyprinid & $\begin{array}{l}\% \\
\text { predatory }\end{array}$ & $\begin{array}{l}\% \\
\text { bioturbators }\end{array}$ \\
\hline TP & $0.697^{\star * *}$ & $0.642^{\star * *}$ & $0.449^{* * *}$ & $0.630^{* * *}$ & -0.040 & $0.328^{*}$ & 0.276 & -0.129 & 0.018 & $0.478^{* * *}$ & $0.607^{* * *}$ & $0.390^{* *}$ & $0.617^{* * *}$ \\
\hline $\mathrm{pH}$ & $0.617^{\star * *}$ & $0.504^{\star *}$ & $0.396^{* *}$ & $0.490^{* * *}$ & 0.139 & 0.019 & 0.131 & $-0.535^{\star * *}$ & -0.106 & $0.507^{\star * *}$ & $0.589^{* * *}$ & $0.379^{* *}$ & $0.546^{* * *}$ \\
\hline Colour & $-0.492^{* * *}$ & $-0.417^{* *}$ & $-0.352^{*}$ & $-0.398^{\star *}$ & -0.133 & -0.236 & -0.161 & $0.380^{*}$ & $-0.280^{*}$ & -0.219 & -0.235 & $-0.335^{\star}$ & -0.255 \\
\hline TON & 0.191 & 0.174 & 0.148 & 0.158 & -0.103 & -0.058 & 0.092 & -0.286 & -0.059 & $0.330^{*}$ & $0.288^{*}$ & 0.193 & 0.197 \\
\hline $\mathrm{NH}_{4} \mathrm{~N}$ & 0.076 & 0.024 & 0.094 & 0.039 & 0.150 & $0.315^{*}$ & $0.449 * *$ & -0.136 & 0.186 & $0.546^{\star * *}$ & $0.332^{\star}$ & 0.146 & $0.359^{* *}$ \\
\hline Chloride & 0.227 & 0.115 & -0.034 & 0.211 & 0.244 & 0.096 & 0.006 & -0.015 & -0.042 & -0.152 & -0.165 & 0.163 & -0.243 \\
\hline $\mathrm{SiO}_{2}$ & $0.425^{\star *}$ & 0.284 & 0.271 & 0.273 & 0.168 & 0.064 & 0.176 & $-0.346^{*}$ & 0.001 & $0.525^{\star \star *}$ & $0.500^{* * *}$ & $0.335^{*}$ & $0.508^{* * *}$ \\
\hline Area & $-0.388^{* *}$ & -0.236 & -0.089 & $-0.286^{*}$ & -0.007 & 0.096 & 0.145 & 0.156 & 0.151 & 0.245 & 0.001 & -0.087 & 0.099 \\
\hline Elevation & 0.128 & 0.127 & 0.210 & $-0.459^{\star * *}$ & $-0.311^{*}$ & 0.081 & -0.032 & 0.240 & 0.118 & -0.242 & -0.097 & 0.047 & -0.067 \\
\hline PopDens & 0.238 & 0.079 & 0.018 & 0.100 & $0.359^{*}$ & 0.176 & $0.306^{*}$ & $-0.384^{* *}$ & 0.020 & $0.394^{\star *}$ & $0.334^{*}$ & $0.305^{*}$ & $0.344^{*}$ \\
\hline MEI & $0.615^{\star * *}$ & $0.465^{\star * *}$ & $0.312^{*}$ & $0.452^{* * *}$ & $0.352^{*}$ & 0.129 & 0.286 & $-0.524^{* * *}$ & -0.175 & $0.502^{* * *}$ & $0.631^{* * *}$ & $0.291^{*}$ & $0.601^{* * *}$ \\
\hline$\%$ agriculture & $0.504^{* * *}$ & $0.517^{\star * *}$ & $0.296^{*}$ & $0.508^{\star * *}$ & -0.055 & 0.009 & -0.009 & $-0.417^{* *}$ & -0.099 & $0.380^{* *}$ & $0.396^{\star *}$ & $0.421^{\star *}$ & $0.386^{* *}$ \\
\hline
\end{tabular}

$761 \quad{ }^{* \star *} P<0.001,{ }^{* *} P<0.01,{ }^{*} P<0.05$ 

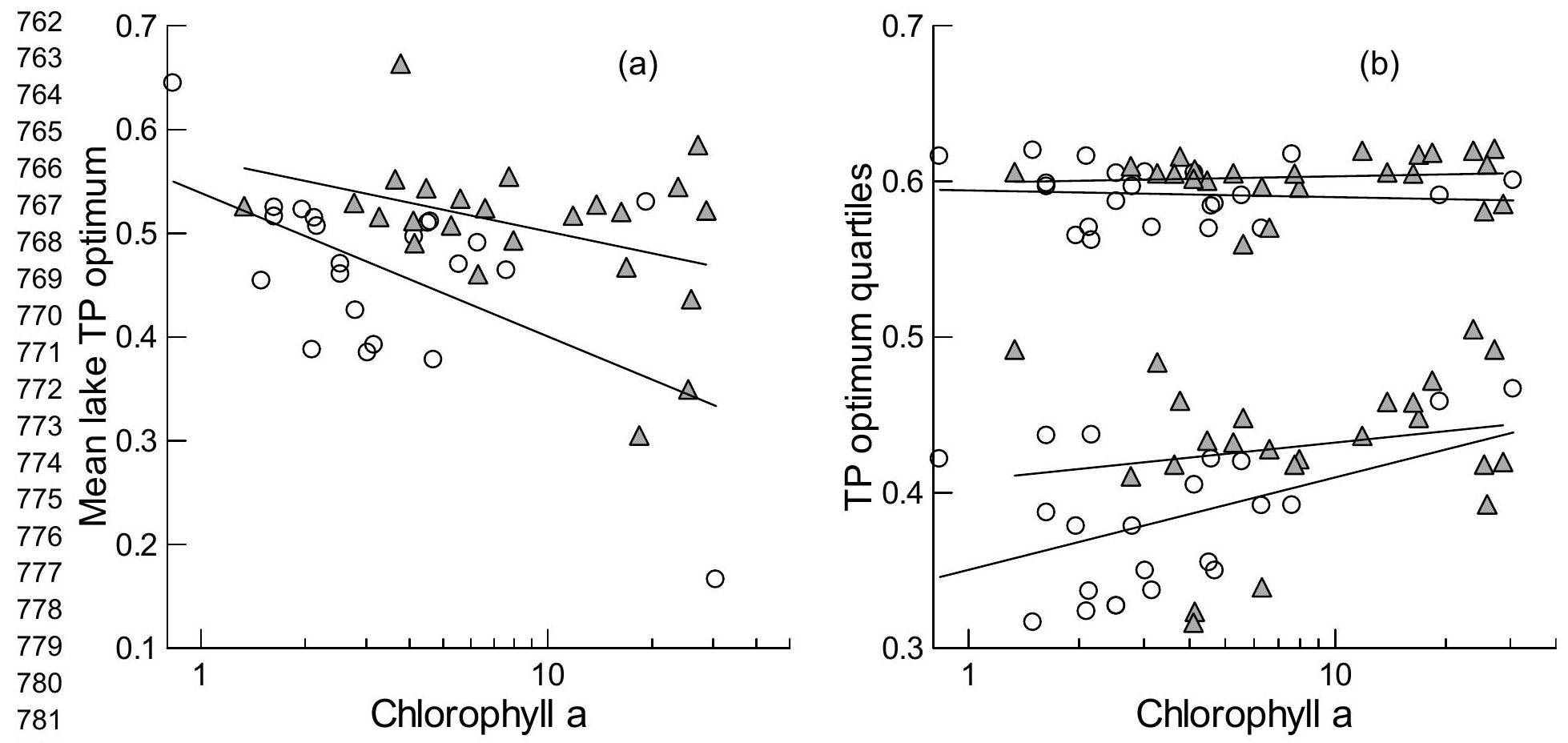

Fig. S1. (a) Mean lake TP optima and (b) upper and lower taxon TP optima quartiles as functions of

784 chlorophyll a concentration in cyprinid (triangles) and cyprinid-free (circles) lakes. In (a) slopes were 785 not significantly different (slopes $F_{1,42}=3.00, P=0.09$, common slope $-0.120 \pm 0.033, P<0.01$ ) but mean

786 TP optima were significantly greater when cyprinids were present (intercepts $F_{1,43}=11.09, P<0.01$ ). In

787 (b) both upper and lower quartiles differ in intercept $\left(F_{1,44}=4.86, P<0.05 ; F_{1,44}=11.38, P<0.01\right.$

788 respectively) but only the lower (TP intolerant) quartile for cyprinid-free lakes varied with Chla $789 \quad(b=0.059 \pm 0.026, P<0.05)$. 